\title{
THE TEACHING OF GEOGRAPHY IN JAPANESE SECONDARY SCHOOLS
}

\author{
RYÛTARÔ ASAKURA
}

Place of Geography in Curriculum

Secondary education in Japan is provided in (a) lower secondary schools, with a three-year course which is compulsory for all pupils, boys and girls alike, on completion of the six years of compulsory primary schooling, and in (b) upper secondary schools, with a three-year full-time course and a four-year part-time course; neither of these courses is compulsory. The pupils are 12,13 and 14 years old in the lst, the 2nd and the 3rd year respectively of lower secondary schools, and 15, 16, 17 and 18 in the 1st, the 2nd, the 3rd and the 4th year respectively of upper secondary schools.

In lower secondary schools, Gengraphy is taught as one field of social studies, composed of three fields - Geography, History and Civics. The time allocation for social studies is 4-6 hours a week (i.e., $12-20 \%$ of the total time table of thirty to thirty-four hours a week) in the 1st year, 4-8 hours (12-27\%) in the 2nd year, and 5-9 hours (15$30 \%$ ) in the 3rd year.

In practice, the time allotted to social studies is as follows according to the survey conducted by the Ministry of Education in September, 1956 :

Hours per week

\begin{tabular}{ccccccc|} 
& 3 & 4 & \multicolumn{1}{c}{5} & 6 & 7 & total \\
lst year & $0 \%$ & $65.5 \%$ & $32.8 \%$ & $1.7 \%$ & $0 \%$ & $100 \%$ \\
2nd " & 0.2 & 55.0 & 41.4 & 3.4 & 0 & 100 \\
3rd " & 0.2 & 26.6 & 62.9 & 9.8 & 0.5 & 100
\end{tabular}

Most of the lower secondary schools offer Geography in the lst year.

In upper secondary schools the credit system is in operation. The various "subject-areas" are mostly subdivided into a number of subjects, and each of these is allotted a certain number of credits (a credit of " 1 " involves one hour of teaching and learning per week throughout the school year of thirty-five weeks). For graduation, each pupil is required to take at least 85 credits ; pupils ordinarily take 90 96 credits.

The social studies subject-area is subdivided into four subjectsCivics (3-5 credits), Japanese History (3-5 credits), World History (3-5 credits) and Human Geography (3-5 credits). Of the four subjects, all 
pupils are required to take three subjects containing Civics; Civics is compulsory and the other three subjects are elective. Human Geography is taken by those pupils who need it in any school year of upper secondary school course.

Physical Geography, as it is called Earth Sciences, has its post in natural sciences subject-area in upper secondary school curriculum, and in Human Geography physical conditions of the earth are studied primarily not for their own sake but to provide data for Human Geography.

\section{Methods of Teaching Geography}

Before World War' II not only was the content of Geography arid but the teaching methods were almost exclusively formal: teaching was mainly didactic in the sense that pupil was a passive receiver. Classroom technique of this kind may still be found; in the extreme case, selected facts are given and generalizations made, everything neatly and logically arranged by the teacher, the blackboard sketch properly copied in the notebook. This technique is somewhat disparagingly called "chalk and talk".

The methods of teaching social studies have been improved since 1947 when "Course of Study in social studies" (the first edition) was published by the Ministry of Education. One of the important movements after the War is the organization of subject matters into large units of work and the development of teaching procedures on the unit system. A unit may be taught in many different ways. The prevailing method of teaching a unit of work is conducted by the "unitcycle" process or technique. By this method a unit is presented or introduced, worked through by teacher and pupils, and brought to a close as a single comprehensible phase of the social environment. The various phases or steps in the "unit-cyele" procedure are shown in the following outline.

Steps in the unit cycle

1. Introduction or presentation of the unit

2. Pupil mastery of the unit

a. Directed study and exploratory reading

b. Supplementary pupil activities

c. Summarization through socialized discussion

3. Evaluation of work on the unit

Indeed such a method of teaching social studies is prevailing especially in elementary schools and is considered desirable in secondary schools also, but in fact is not widely used in secondary schools. It is considered to have many external difficulties: most classes have more than fifty pupils, most schools have not special classrooms for social 
studies, most schools have not enough audio-visual aids to be utilized, above all this method is not felt to economize the time available for the examination program. On purely educational grounds this may possibly be deplored. We should develop newer and more effective methods of teaching suited to our educational conditions, synthesizing the pre-war lecture methods and post--war unit teaching procedures.

Though the method of teaching social studies in operation is above mentioned, that of teaching Geography has been comparatively improved; in teaching geography, there are wider implications such as visual aids, group work, local geography, projects and field study; and as a matter of fact, this is the subject in which we may apply the unit teaching procedure most easily and effectively among all the subjects within the social studies subject-area.

Teachers are to use those textbooks and atlases authorized by the Ministry of Education. Such authorization is based on official requirements in respect of up-to-dateness, organization, style, and adaptation to the level of the pupils.

\section{Teachers}

The qualification of Geography teaching in secondary schools follows that of Social Studies teaching.

The qualifications secondary school Social Studies teachers are required to possess, are laid down in the Educational Personnel Certification Law. Such teachers must hold at least a first degree, and must have taken a number of credits varying according to their teachercategory (first class, second class) and. whether they teach at lower or upper secondary school level.

Those specialized subjects and their minimum number of credits to be qualified as secondary school social studies teachers are as follows:

Japanese History and Foreign History

Geography (including Topography)

6 credits

(Law, Political Sciences, Sociology,

Economics, Public Hygienics)* 4 credits

(Philosophy, Ethics, Science of Religion)*

4 credits

Total

20 credits

* More than one subject are studied picked out

of bracketed subjects.

Percentage of teachers possessing certificates of Social Studies in 1956 is as follows:

the first class

(a) lower secondary schools

the second class

$39.1 \%$

(b) upper secondary schools

$44.2 \%$

51.9 

provisional
3.1
1.9
temporary
4.1
2.0
Total
100.0
100.0

as indicated above, about $7 \%$ of teachers of lower secondary schools and about $4 \%$ of upper secondary schools have not, to our regret, regular certificates. According to another survey, about 15\% of teachers of Social Studies in lower secondary schools are in practice without the required qualifications (1953).

Considering teachers of Geography, it is desirable that responsible teachers of Geography should possess a university degree or an academic diploma in their subject, but it should also be recognised that many graduates majored other subjects, either arts or sciences, are teaching geography after graduation without being able to follow it up by taking a second certificate or other special qualification.

The present system of education for prospective secondary school teachers, which requires a normal four-year university degree course is said to have failed, sometimes, to prepare efficient teachers because it has not always developed enough the personal qualities so essential to desirable teaching. A greater effort is expected to encourage the recruitment of the graduate student with a relatively mature sense of profession.

Secondary teachers of Social Studies, including Geography; have various opportunities of obtaining further training. There are facilities for in-service training at university level; workshops and conferences are conducted by the Ministry of Education, the local and prefectural boards of education, and the associations of Social Studies teachers or of Geography teachers; a number of educational journals are available, including the quarterly "New Geography" edited by the Japanese Association of Professional Geographers.

\section{Use of Audio-Visual Aids and Classroom Arrangements}

Full details of School Broadcasts can be obtained from Japan Broadcasting Corporation (N.H.K.), Uchisaiwai-cho, Chiyoda-ku, Tokyo. In addition to the full programme, registered schools receive teacher's leaflets which contain background notes, book lists, suggestions for preparation and follow-up activities. There are two main broadcasting programs on secondary school geography.

(1) "Geography"

(2) "How the world is moving" international understanding.

These are planned for

One of the chief functions of geography in schools is to help pupils imagine accurately places, people and their activities which lie beyond direct experiences. It aims at creating in the pupils' mind clear impres- 
sions concerning the characteristics of a place, what it looks like and feels like to be there. Utilizing always the pupils' experiences as the starting-point, the teacher of Geography has, in addition to many other aids - not least the blackboard-a wide range of visual methods to assist him.

The Ministry of Education adapted a standard number of audiovisual aids according to the number of classes in lower secondary schools and in part-time courses of upper secondary schools, and conducted the nationwide survey in October 1954.

Concerning those lower secondary schools which have 6-7 classes (about $60 \%$ of all lower secondary schools), the standard and ratio of equipment for social studies are as follows:

\begin{tabular}{|c|c|c|}
\hline & $\begin{array}{l}\text { Standard } \\
\text { number per } \\
\text { one school }\end{array}$ & $\begin{array}{l}\text { Percentage } \\
\text { of equipment } \\
(\%)\end{array}$ \\
\hline \multicolumn{3}{|l|}{ Implements common to all subiects* } \\
\hline Magic lantern apparatus & 1 & 70 \\
\hline Epidiascope & 1 & 10 \\
\hline $16 \mathrm{~mm}$ Motion film projector & 1 & 7 \\
\hline Screen & 3 & 19 \\
\hline Camera & 1 & 21 \\
\hline Broadcasting implements in a scho & ool & 87 \\
\hline Wireless set & 1 & 78 \\
\hline Tape recorder & 1 & 37 \\
\hline Bulletin boards & 6 & 63 \\
\hline Small portable blackboards & 12 & 55 \\
\hline Section blackboards & 6 & 60 \\
\hline Copying press & 2 & 37 \\
\hline Magnet & 6 & 12 \\
\hline \multicolumn{3}{|l|}{ Implements for geography } \\
\hline Specimen set & 1 & 4 \\
\hline Relief model set & 1 & 16 \\
\hline Large globe & 1 & 79 \\
\hline Maps of each prefecture (series) & 1 & 39 \\
\hline Wall map of Japan & $\therefore \quad 1$ & 93 \\
\hline Wall maps of each province in Jap & Wall maps of each province in Japan & 86 \\
\hline Wall map of the world & 1 & 92 \\
\hline Wall maps of each continent (serie & es) & 80 \\
\hline Map of Japanese climate & 1 & 21 \\
\hline Map of the world climate & 1 & 16 \\
\hline Map of Japanese industries & 1 & 29 \\
\hline
\end{tabular}


Map of the world industries $\quad 1 \quad 26$

Wall map of one's native country 1169

Marine charts $\quad 1 \quad 5$

Film $\quad 3 \quad 9$

Film strips (series) $\quad 10 \quad 5$

Slides (series) $\quad 10 \quad 28$

* Only those implements closely connected with teaching geography were picked up.

In addition, Ordinance Survey maps, especially 1:50,000 maps, are familiarly used in teaching geography.

Our country recieved severe damages from World War II and many schools were destroyed. We have tried hard to build school houses for about these ten years, but have not enough, to say nothing of special class-rooms for geography. According to the survey in 1954, only $5 \%$ of lower secondary schools have special classrooms for social studies.

\section{Relationship between Geography and International Understanding}

It is generally agreed that improved international understanding is a goal worth aiming at, but that it should be developed through the objective learning of various school subject-areas. Both the geographical field in lower secondary school curriculum and the human geography in the upper secondary school curriculum, by their very nature, are particularly suitable mediums for this purpose, and many teachers of geography have been interested in the fostering of international understanding through their teaching.

The obiectives of teaching geography are closely related with the development of international understanding which are stated in the "lower secondary school course of study in social studies" as follows:

'Contributory Objects of Geographical Field.....

1. To develop an understanding of the characteristic features of every land and people, and through such understanding to develop an attitude to see peoples of other regions with neither prejudice nor preconception.

2. To develop an understanding of the interdependence of men and nations, and through such understanding to develop a sense of individual obligation as a member of human being as well as a member of our native country and our mother country in this close world.' While on the other hand, the "upper secondary school course of study in social studies" states:

'Objectives of Human Geography.....

(1) To develop an understanding that all lands and peoples of the 
world are closely bound together, and that they, performing their particular functions within the total structure called as the World, have their own problems to be solved.

(2) To develop an understanding and a sympathetic appreciation of other lands and peoples, to help to be aware of similar humanity in all their different modes of life and living, and through such understanding to develop an attitude and a habit to work together in order to solve various geographical problems.'

Two approaches are open to the gaography teacher who wishes to foster international understanding - 'international affairs geography' and 'way of life geography'. Both may be introduced at any level of the school course, although it is natural that the latter should be emphasized in the lower secondary school curriculum, and the former in the upper secondary school curriculum. But it is important to emphasize that the geography teacher is not teaching international understanding' only, but is teaching geography to pupils so that they may be encouraged to think critically and with understanding. Primarily, international understanding grows out of the pupil's accurate knowledge and critical appraisal of geographical facts, and should not, and most probably cannot, be instructed verbally.

Japanese National Commission for Unesco is in full play in the eduçation for international understanding and co-operation. It has requested six secondary schools to be the associated schools and about thirteen to be $\mathrm{Co}^{-}$operative. A Report was issued in English on the experimental activities carried out in Japan during the period between 1954 and. July 1955, with two main topics of (1) Study on human rights and (2) Understanding of other countries.

According to the Course of Study in Social Studies as revised in October 1958, Geography is to be offered as a rule at least 4 hours per week in the lst year starting from the school year of 1962 . 